\title{
Strategic Inventory Management Practices and the Performance of Supermarkets in Nairobi County, Kenya
}

\author{
Robert M. Arasa and John O. Achuora
}

\begin{abstract}
This study establishes the influence of strategic inventory management practices on the performance of supermarkets in Nairobi County, Kenya. Specifically, the study examined the effect of vendor managed inventory, leaninventory system, e-inventory management system and activitybased costing system on performance of supermarkets in Nairobi County. The study was grounded on the resource based view theory. A descriptive cross-sectional survey research design was employed and stratified random sampling approach used to ensure representativeness of the study population. From the target population of 158 supermarkets a sample size of 113 supermarkets was picked. A structured questionnaire was used to collect primary data and was administered to the heads of supply chain management in the respective firms. Descriptive statistics and multiple regression equation were applied to analyse data with the help of Statistical Package for Social Sciences (version 21.0). The study established a positive significant relationship between strategic inventory management practices and performance of supermarkets. Explicitly, e-inventory management system and activity-based costing system registered the highest influence on performance of supermarkets while lean inventory management systems had no significant influence on performance. The study concludes that strategic inventory management practices significantly improve performance of supermarkets. Consequently, the study recommends that management of supermarkets in the County should implement e-inventory management systems and practice activity-based costing in order to improve their performance through reduction of operation costs and improved inventory control, the management of supermarkets should institutionalize employment of cost accountants as part of supply chain management team for effective application of activity based costing in inventory management. and the government should give tax rebate on IT infrastructure related to e-inventory management systems to encourage up take of the systems by firm as a way of boosting their performance and growth. Further the study suggests that future research should focus on undertaking a comparable study incorporating a wider spatial and population scope as well as give attention to constructs affecting the effectiveness of strategic inventory management practices once they are implemented by supermarkets in order to obtain a comprehensive understanding of the subject matter and contribute towards the existing body of knowledge in this area.

Index Terms - vendor managed inventory, lean inventory, einventory, activity base costing, performance, supermarkets.
\end{abstract}

\section{INTRODUCTION}

Due to the complexity of providing businesses with supplies and shipment of products, inventory holding developed as a business concept in the 1950 s, a time which saw corporations hold massive quantities of stock as it was not only considered best practice but also a sign of wealth [9]. This school of thought was challenged in the late 1970s and early 1980s when it was revealed that there was high cost of money involved in holding inventory [9]. This forced a reevaluation of the benefits of holding inventory and companies started working on alternative concepts of managing their inventories [23]. The origin of inventory management is unclear but according to reference [17], the practice quickly became an issue for merchants when supermarket format quickly dominated the retail landscape after World War II.

Today inventory management is not only considered a cost-cutting method but according to reference [14], it is a competitive weapon which when strategically employed may lower inventory carrying costs, improve market share and customer service levels and essentially improve performance of firms in the retail industry. Reference [8], defines inventory management as a daily method for ordering, processing, receiving and maintaining stock. Thus strategic inventory management practice (SIMP) can be defined as, the process of planning, ordering and controlling of stock items in a manner that contributes to performance of firms [9]. Reference [8] further defined strategic inventory management to mean inventory management styles capable of giving a firm a competitive advantage resulting to significant performance. Reference [8] postulated the inventory management styles to include practices such as activity-based costing, lean inventory system, vendormanaged inventory, and e-inventory management system. This study therefore sought to establish the influence of these inventory management styles on the performance of supermarkets in Nairobi County, Kenya.

Kenya's supermarkets comprise of a mixture of large retail outlets that supply consumer goods from major international firms and small traders that sell more basic goods [20]. As at 2014 the four large home grown chains dominating the retail market included; Nakumatt with 57 branches, Tuskys 45 branches, Naivas 36 branches and Uchumi 27 branches; all of which stock a variety of products including food, home and personal care, electronics and clothing [27]. However, reference [22], report that an alarming two thirds of retail firms in Kenya drop out of the growth curve of the product lifecycle with cases of supermarkets shutting down (such as Jack and Jill, Payless) and/or withdrawing from regional markets (such as Uchumi, Nakumatt), within the first few years of expansion. This has resulted in criticism of strategies 
being used by the management of supermarkets [54], [17]. Reference [22] assert that, the performance of supermarkets depends a great deal on the service levels provided by stock management. Further, as reported by reference [23], a number of supermarkets in Kenya have started embracing strategic inventory management concept in an attempt to solve performance issues. Reference [22] nevertheless notes that the impact of strategic inventory management on performance is yet to be conclusively empirically confirmed, hence this study.

\section{Statement OF THE Problem}

Vision 2030 highlights retailing as one of the most important sector(s) in this country, as it accounts for approximately 10 percent of the GDP and 10 percent of formal employment [6]. Reference [13] adds that, the sector serves as an important tax collection point as value added tax (VAT) is gathered at the retail level in this country; and similarly contributes to the social welfare of consumers by offering goods at reasonable prices [6], [13]. Thus, the vision emphasizes the need to improve performance and raise productivity in retail trade as the economy heads towards a 10 percent growth rate [6]. Nevertheless, the retail industry in Kenya has been mired with several challenges, in recent years, with the important players such as Nakumatt, Uchumi and Tuskys enduring worrisome financial woes, accompanied by empty shelves, closure of branches both locally and regionally and complaints by unpaid suppliers [31]. Ebrahim supermarket is near extinct and Jack and Jill and Ukwala supermarkets have closed shop. Consequently the contribution of the retail sector to the GDP has been progressively declining; standing at 8.0 percent in 2014 and further declining to 7.5 percent as at 2015 [13] raising doubt on the sector ability to effectively contribute to the realization of the country Vision 2030. This then calls for a new approach with potential of improving performance of the supermarkets in order to realize Vision 2030 milestones [6]. Strategic inventory management concept has been hypothesized to have significant effect on performance of retail firms [31], [17] through reduction of operation costs, effective control of inventories, untying working capital and improvement of customer services [8].

Therefore, the concept of strategic inventory management is gaining traction resulting in a number of retail firms in Kenya embracing the concept in an attempt to change their performance fortune [13]. However there have been minimal researches that conceptualize the strategic inventory management practice - performance link within the retail industry in Kenya [10]. Further, the existing empirical literature focuses more on other continents other than Africa such as America, Europe, and some parts of Asia [28]; hence the study on the influence of strategic inventory management practices on the performance of supermarkets in Nairobi County, Kenya

\section{STUdy OBJECTIVES}

This study sought to ascertain the influence of strategic inventory management practices on the performance of supermarkets in Nairobi County, Kenya. Specifically the study set out to; determine the influence of vendor-managed inventory, lean inventory management system, E-inventory management systems and activity-based costing systems on the performance of supermarkets in Nairobi County. In addressing these objectives, answers to the following questions were sought; what is the influence of vendormanaged inventory practice, lean inventory management systems, E-inventory management system and activity-based costing (ABC) systems on the performance of supermarkets in Nairobi County, Kenya?

\section{NEED AND SCOPE OF THE STUDY}

This study was necessitated by the need to find a solution for performance challenges facing the retail sector in Kenya especially the supermarkets. The study was needed to provide way forward on comprehensive stock management measures with the potential of reducing operation costs, improve customer services and ensure effective stock control as well as uncover many potentially neglected areas in inventory management literature such as the relationship of strategic inventory management and performance.

The study advanced strategic inventory management practices namely: activity-based costing, lean inventory system, vendor-managed inventory, and e-inventory management system as solutions to the declining performance of supermarkets in Kenya with Nairobi County being selected as the representative county of study due to its unique status of being home to the largest number of supermarkets in Kenya totaling to 158 according to reference [32] which exist in all forms, giving it a representative status. The study adopted profitability as a measure of firm performance as advocated by references [54]. Head of supply chain management in the respective firms were used as the unit of observation. The study covers January to March, 2019 period.

\section{LITERATURE REVIEW}

\section{A. Theoretical Review}

A Theory is developed to explain phenomena as well as challenge and extend existing knowledge within the limits of proven facts [26]. The theoretical review introduced and described a theory which explains why the research problem under study exists. The study therefore is grounded on resource based view theory as advanced [7] and activity based cost system [37], [40] and [36]. These theories are discussed in the section to follow:

\section{Resource Based View Theory}

The theory states that the resources and capabilities of a firm are central when it comes to strategy formulation. Reference [7] reveals that firms have within their possession, resources that can enable them to achieve competitive advantage by taking an inverted view of why companies succeed or fail. Reference [26] add that, resources are valuable and rare, the benefits of which can be utilised by the firm, to provide the firm with a temporary competitive advantage as well a long term competitive advantage depending on the extent to which the firm is able to protect 
against resource imitation, transfer, or substitution [4], [26].

This theory requires that the company begins by considering its own internal environment and then try and assess the strategy that would be considered the best to maximize its performance [7]. Reference [4] state that the success of a firm largely depends on its internal competencies. Reference [26] suggested that strategic inventory management practices such as activity-based costing, lean inventory system, vendor-managed inventory, and e-inventory management system are such internal capabilities that can be used by supermarkets to obtain competitive advantage thus performance. Reference [26] posit that to obtain competitive advantage, firms require resources that cannot be duplicated and strategic inventory management concept is a resource that can be customized to give retail firms a competitive edge in the industry through reduction of cost of operation, improved customer service and effective stock control [26].In particular, the theory provides a logical framework to examine the strategic value of activitybased costing, lean inventory system, vendor-managed inventory, and e-inventory management system and guides on how to distinguish their impacts on performance from the numerous kinds of supply chain management concepts [26], [4].

\section{Activity Based Costing (ABC) System Theory}

Activity-based costing ( $\mathrm{ABC}$ ) is a costing method that identifies activities in an organization and assigns the cost of each activity to all products and services according to the actual consumption by each [36]. This model assigns more indirect costs (overhead) into direct costs compared to conventional costing [36]. It identifies cost groups of activity centers in organizations and allocates costs to products and services based on a number of events or transactions that are absolutely necessary in a process to deliver the product or service [38]. According to reference [36], [39] and [38], ABC concept constitutes elements such as activity dictionary, cost estimation, cost drivers identification and cost assignment. Additionally, Reference [37] avers that ABC elements stimulate a search for improvements of the production process through cost-consciousness in material management.

Activity Based Costing (ABC) is a system that goes beyond traditional cost price models with respect to indirect cost calculation models [37]. This method was developed in the United States [37]. Robert Kaplan is regarded as the founder of the theoretical principles of activity based costing within the cost management knowledge area [40]. At initial stages around 1987, the principle was mainly used by the Consortium of Advanced Manufacturing-International (CAM-I) [36]. However, the theory was later applied in stock management by retailing firms [39]. According to reference [38], ABC can be applied by retail firms to identify activities which do not add value and should therefore be eliminated. In this manner, improvements can be realized that can lead to higher performance results [38] in the retail sector. Reference [39] added that the concept could potentially contribute to strategic developments within cost price calculations which may lead to price differentiation of the organization products and better customer service. Further, reference 41 ] noted that accurate cost information can help an organization respond to competitive advantage and certain decisions.

\section{B. Empirical Review}

\section{Vendor- Managed Inventory and Firm Performance}

Vendor-managed inventory (VMI) started as a quick response (QR) in the 1980s when groups of retailers demanded that suppliers take up the responsibility of replacing inventory, as a reaction to the challenges of lack of demand visibility resulting in insufficient capacity utilization, poor product availability and excess stock levels [31], [28]. Reference [31] study revealed that VMI positively influences inventory management cost through elimination of holding costs. The research used a case study design and targeted 100 heads of supply chain management of manufacturing firms in Udaipur, India. A sample size of 25 respondents participated in the survey. The Study focused on private manufacturing firm. Reference [28] study established a correlation between VMI and stock management cost and customer service. The study used desk top survey of 155 firms and the study lasted for a period of three months.

\section{Lean Inventory Management System and Firm Performance}

Lean thinking is a business excellence philosophy that originated in the manufacturing sector; pioneered by Womack et al in 1990s, with the aim of identifying and minimizing wastages, so as to simplify and make the operations smooth [31]. This was confirmed by reference [19] which established, through a study of textile and apparel sector in India, that lean inventory management system increase efficiency, reduce execution time, reduce waste of all kinds, increase profitability and keep low inventories. Reference [11] surveyed wallmatt operations and reported increased application of lean inventory management system in the firm's operations. They further reported increased cost efficiency, increased worker productivity and less waste of time and effort; which in return significantly improves customer satisfaction and store profitability as a result of lean inventory management. They concluded that lean inventory management system had a positive impact on wall-mart performance.

\section{E-Inventory Management System and Firm Performance}

Information, communication technology (ICT), has been termed the driving force behind accelerated business growth in the 21st century; reference [31] call it the life blood of an organization. ICT is defined as "any technology which supports activities involving the creation, storage, manipulation and communication of information; together with their related methods, management and application" [4]. Based on this, reference [19] conducted a study on the influence of e- inventory management system on performance in the retail industry. The empirical results were derived from mail survey responses of 111 South African and 
116 New Zealand retailers. The study concluded that einventory management system positively influence performance in retail industry.

Reference [25] empirical study revealed a positive relationship between e-inventory management system and performance. The study was based on equipment manufacturer of the automotive industry located in Mexico an empirical study in Mexico. Data was collected through a survey of operation managers for original equipment manufacturer of the automotive industry located in Mexico. The findings suggested that electronic data interchange, electronic point of sale, bar coding and radio frequency identification increases traceability of stock, monitoring of stock, replenishment of stock, accuracy in recording and issuance thereby increases efficiency in stock management and reduces cost of operation.

\section{Activity Based Costing (ABC) System and Firm Performance}

Originally designed for manufacturing companies, by professors Robin Cooper and Robert Kaplan to amend the misleading allocation of overheads to products or services; several advancements have since been made and today application of activity based costing has spread to all sectors of the economy including service corporations [7]. According to reference [4] $\mathrm{ABC}$ is a costing method that identifies activities in an organization and assigns the cost of each activity to all products and services according to the actual consumption by each. A study by reference [28] in the telecommunication industry established a positive significant relationship between $\mathrm{ABC}$ and the performance of firms. The study used a descriptive research design and a total of 526 firms were surveyed. Another study in the retail industry by reference [3] concluded that $\mathrm{ABC}$ is an effective tool to manage costs and wastes within the operation of Mercadona supermarkets. The study surveyed 312 supermarkets and a cross-section survey research design was applied in the study. Further, reference [3] established a positive correlation between $\mathrm{ABC}$ and right pricing of products to customers which make customers trust the firm and become loyal hence performance due to repeat purchases.

\section{Conceptual Framework}

The theoretical review provided the basis for the development of the conceptual framework for the study. According to reference [26] under the resource based view theory, strategic inventory management practices are unique internal resources with potential to significantly improve performance of a firm. Thus the study tested hypothetical model arising from the conceptual framework presented in figure 1 .

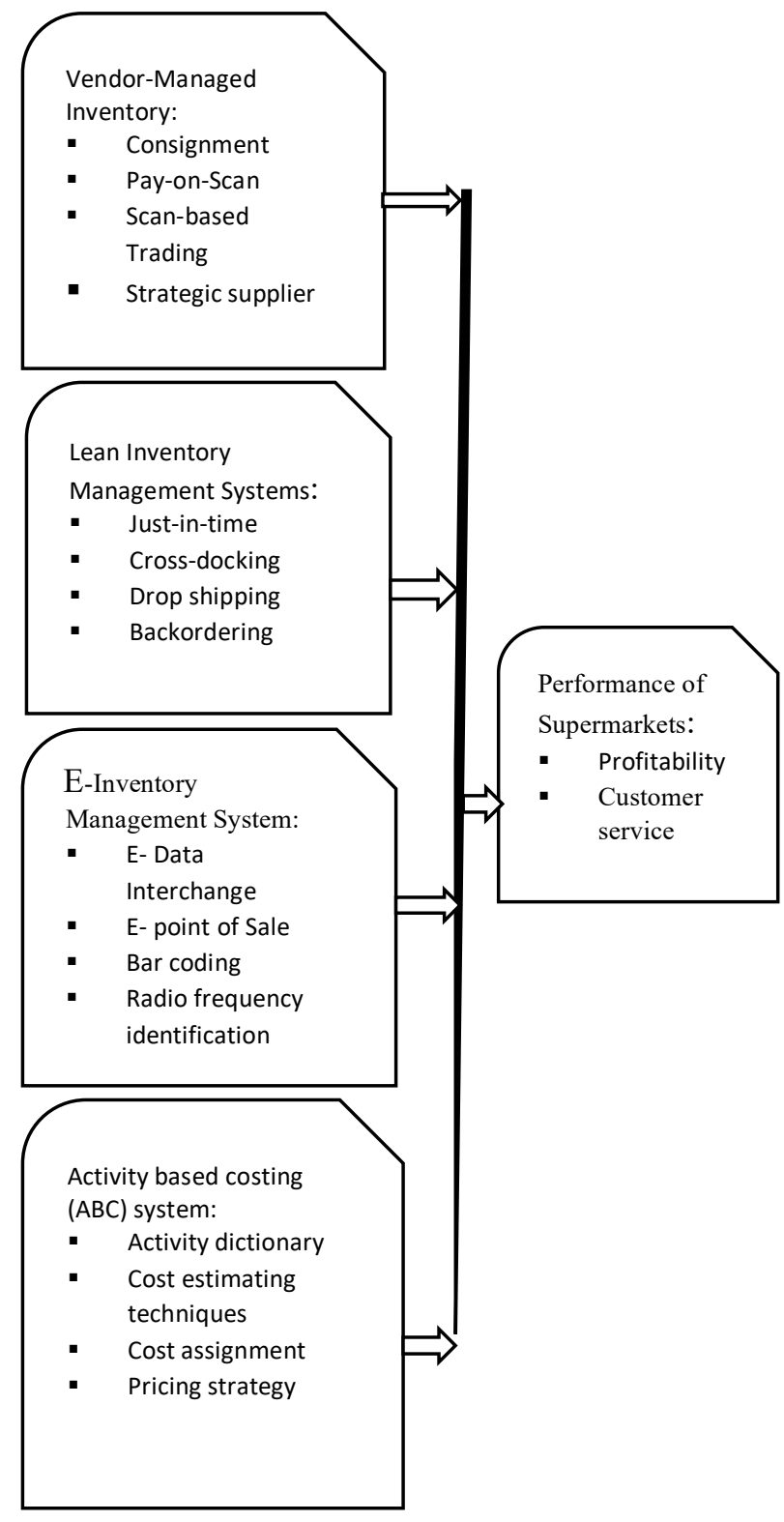

Fig. V. 1: Hypothesized relationship between Strategic Inventory Mgmt. and Supermarket Performance

\section{Operationalization and Measurement of the variables}

To test the hypothetical relationship model, it needed to be operationalized. Operationalization involved identification of the constructs, constructs measures and measurement scales. These are presented on Table V.1. 
TABLE V.1: OPERATIONALIZATION AND MEASUREMENT OF THE VARIABLES

\begin{tabular}{|c|c|c|c|c|}
\hline Constructs & Type & $\begin{array}{l}\text { Operationalization/ } \\
\text { Indicators }\end{array}$ & $\begin{array}{l}\text { Meas } \\
\text { urem } \\
\text { ent } \\
\text { Scale }\end{array}$ & Sources \\
\hline $\begin{array}{l}\text { Vendor- } \\
\text { Managed } \\
\text { Inventory }\end{array}$ & IV & $\begin{array}{ll}\text { - } & \text { Consignment } \\
\text { - } & \text { Pay-on-Scan } \\
& \text { Scan-based } \\
\text { - } & \text { Srading } \\
& \text { Strategic } \\
\text { supplier } \\
\text { partnership }\end{array}$ & $\begin{array}{l}\text { Aggr } \\
\text { egate } \\
\text { inde } \\
x \text { of } \\
1-5\end{array}$ & $\begin{array}{l}{[31,[28],} \\
{[6]}\end{array}$ \\
\hline $\begin{array}{l}\text { Lean Inventory } \\
\text { Management } \\
\text { System }\end{array}$ & IV & $\begin{array}{ll}\text { - } & \text { Just-in-time } \\
\text { - } & \text { Cross-docking } \\
\text { - } & \text { Drop shipping } \\
\text { - } & \text { Backordering }\end{array}$ & $\begin{array}{l}\text { Aggr } \\
\text { egate } \\
\text { inde } \\
x \text { of } \\
1-5\end{array}$ & $\begin{array}{l}{[19] .[31] .} \\
{[11]}\end{array}$ \\
\hline $\begin{array}{l}\text { E-Inventory } \\
\text { Management } \\
\text { System }\end{array}$ & IV & $\begin{array}{ll}\text { - } & \text { E- Data } \\
\text { - } & \text { Interchange } \\
& \text { E- point of } \\
\text { - } \quad \text { Sale } \\
\text { - } \quad \text { Rar coding } \\
\text { frequency } \\
\text { identification }\end{array}$ & $\begin{array}{l}\text { Aggr } \\
\text { egate } \\
\text { inde } \\
x \text { of } \\
1-5\end{array}$ & $\begin{array}{l}{[7],[19],} \\
{[31]}\end{array}$ \\
\hline $\begin{array}{l}\text { Activity based } \\
\text { costing (ABC) } \\
\text { system }\end{array}$ & IV & $\begin{array}{ll}\text { - } & \text { Activity } \\
\text { dictionary } & \text { Cost } \\
\text { - } & \text { estimating } \\
\text { techniques } \\
\text { - Cost } \\
\text { - } \quad \text { Pricing } \\
\text { strategy }\end{array}$ & $\begin{array}{l}\text { Aggr } \\
\text { egate } \\
\text { inde } \\
x \text { of } \\
1-5\end{array}$ & $\begin{array}{l}{[4],[7] .} \\
{[28],[3]}\end{array}$ \\
\hline $\begin{array}{l}\text { Supermarkets } \\
\text { Performance }\end{array}$ & $\mathrm{DVt}$ & $\begin{array}{l}\text { - } \quad \text { Profitability } \\
\text { - } \quad \text { Customer } \\
\text { service }\end{array}$ & $\begin{array}{l}\text { Aggr } \\
\text { egate } \\
\text { inde } \\
x \text { of } \\
1-5\end{array}$ & {$[11],[31]$} \\
\hline
\end{tabular}

\section{RESEARCH METHODOLOGY}

\section{A. Research Design}

The A descriptive cross sectional survey research design was used in this study. Descriptive cross sectional survey research design is a study in which the variables or a set of information is collected for a defined population at specific point in time [12], [16]. The design was preferred because of its ability to provide a good picture of exposure and outcome and compares many variables at the same time at minimum cost [15]. Further, it gives a report on things as they are (Saunders, [16], [15]

\section{B. Population and Sampling}

The target population for the study was all the 158 supermarkets in Nairobi County [32]). The Nairobi County was chosen for the study largely because it is home to all kinds of supermarkets and about $50 \%$ of the total supermarket population in Kenya is based in Nairobi County.

The sampling frame in this study was the entire list of 158 supermarkets as published by the Kenya bureau of statistics [32].
From the target population of 158 supermarkets, the sample size was computed based on reference [33] sample size formula as shown in Equation shown below:

$$
n=\frac{N}{1+N e^{2}}
$$

Where:

$$
\begin{aligned}
& \mathrm{n}=\text { Sample size } \\
& \mathrm{N}=\text { Population size } \\
& \mathrm{e}=\text { the error of Sampling }(0.05)
\end{aligned}
$$

Source: Sample size Formula [33]

The formula was applied in computing the sample size as follows:-

$$
=\frac{158}{1+158(0.05)^{2}}=113.261 \simeq 113
$$

Further, the study made use of stratified random sampling procedure to select respondents. A Simple random sampling was then used to select a sample from each strata (size) as recommended by reference [17]. Respondents for each stratum were computed based on their weight according to reference [34] allocation formula as follows;-

$$
n_{h}=\left(\frac{N_{h}}{N}\right) n
$$

Where:

nh - The sample size for stratum $h$,

$\mathrm{n}$ - Total sample size

$\mathrm{Nh}$-The population size for stratum $\mathrm{h}$,

$\mathrm{N}$ - The total population

Source: Random Sampling technique formula [34])

Additionally, the study used purposive sampling to select the unit of observation (heads of supply chain management). Purposive sampling is a non-probability sampling based on characteristics of a population and the objective of the study [12]. The respondents were selected based on their knowledge of the subject of study: inventory handling and management, e-inventory solutions employed by the organization, pricing and payment decisions as well as procurement practices [4].

\section{Data collection Instruments}

A questionnaire was used to collect primary data. The questionnaire had structured closed questions to guide the respondents. The questionnaire was divided into: section A, which gathered general information about the respondents and their institutions; Section B gathered data on strategic inventory management practices; and section $\mathrm{C}$ gathered data on supermarket performance. The primary data was captured using a five point Likert type scale. In applied management studies, the Likert type scale is one of the acceptable techniques for measurement of attitudes in a "scientific" way, which allows the use of statistical tools to analyze data [5].

The questionnaires were self-administered through email. Email method was chosen in this study due to its efficacy, specific to time and cost [5]. All the email addresses were obtained from the Nairobi Business Directory and 
personalized email sent to all the respondents requesting them to respond within seven working days. Thereafter reminders were sent to all those who failed to respond within the stipulated time. This was repeated until an acceptable rate of responses were received.

\section{Reliability and Validity tests of constructs}

\section{Reliability Test}

Data collection instrument was piloted to test for its reliability and validity. The Cronbach's Alpha Test of Reliability was used to test the reliability of the constructs in the study and the results were as follows: vendor managed inventory had an alpha score of 0.7254 , lean inventory management system, e-inventory management system and activity based costing (ABC) system had alpha scores of $0.7713,0.7101$ and 0.7274 respectively. Alpha values measure the level of internal consistency of the constructs. A closer alpha values to one indicates a higher consistency. According to reference [35] a-score exceeding 0.7 indicates high internal consistency and thus high internal reliability of the scaled items. The attained alpha scores indicate an acceptable level of reliability of the measures. The table 2 shows the reliability test results based on the piloted data.

Table VI.1: Reliability test results

\begin{tabular}{lccl}
\hline Constructs & $\begin{array}{c}\text { Cronbach } \\
\text { Alpha }(\alpha- \\
\text { score) }\end{array}$ & $\begin{array}{c}\text { No. } \\
\text { of } \\
\text { Items }\end{array}$ & $\begin{array}{l}\text { Interpretation } \\
\text { According to } \\
\text { reference [35] }\end{array}$ \\
\hline $\begin{array}{l}\text { Vendor managed } \\
\text { inventory }\end{array}$ & 0.7254 & 4 & Acceptable \\
$\begin{array}{l}\text { Lean inventory } \\
\text { management }\end{array}$ & 0.7713 & 4 & Acceptable \\
system, & & & \\
$\begin{array}{l}\text { E-inventory } \\
\text { management }\end{array}$ & 0.7101 & 4 & Acceptable \\
system \\
$\begin{array}{l}\text { Activity based } \\
\text { costing (ABC) } \\
\text { system }\end{array}$ & 0.7274 & & \\
\hline
\end{tabular}

\section{Validity Test}

Validity is the accuracy and meaningfulness of inferences, which is based on research results [15]. To achieve construct validity of the instrument, the factors measures were derived from the related study theories and were validated by the subject experts [16]. In order to achieve both face and content validities of the instrument, the subject experts looked at the items in the questionnaire and agreed that the tests were valid measures of the study concept [16].

\section{E. Data Processing, Analysis and Presentation}

The collected data was keyed in and processed through the SPSS version 18. SPSS version 18 was preferred due to its Automated Data Preparation feature (ADPF) which can provide multiple comparisons of data and allows tables' customization. Multiple regression analysis was used to establish the influence of strategic inventory management practices on the performance of supermarkets. Regression analysis was preferred due to its ability to model and analyse several variables. The multiple regression equation applied in this study was modelled as follows:

$$
\begin{aligned}
& \mathrm{Y}=\beta 0+\beta 1 \mathrm{X} 1+\beta 2 \mathrm{X} 2+\beta 3 \mathrm{X} 3+\beta 4 \mathrm{X} 4+\varepsilon \\
& \text { Where: } \mathrm{Y}=\text { Dependent variable (profitability) } \\
& \mathrm{X} 1=\text { Vendor-managed inventory } \\
& \mathrm{X} 2=\text { Lean inventory systems } \\
& \mathrm{X} 3=\text { Information communication technology } \\
& \mathrm{X} 4=\text { Activity-based costing systems } \\
& \varepsilon=\text { Constant }
\end{aligned}
$$

A simple linear regression equation in the form $\mathrm{y}=\mathrm{B} 1 \mathrm{X} 1$ $+\varepsilon$ was applied for each variable in relation to performance so as to obtain values of the regression co-efficient - ' $r$ ' which measured the strength and direction of the linear relationship between the variables, and R-squared (R2) value to show the percentage of performance attributable to the independent variables. A t-test was also done at a p-value of significance level $p \leq 0.05$. The results of the analysis are presented using frequency tables with a view to absolutely reveal data patterns together with explanations in continuous prose.

\section{RESULTS AND DISCUSSIONS}

\section{A. Response Rate}

A total of 113 respondents were issued with questionnaires, out of which, 85 questionnaires were filled and returned. This gave a response rate of $71 \%$. This was considered sufficient for this study in line with reference [12] recommendation that a response rate of $80 \%$ and above is excellent while that of between $60 \%$ and $80 \%$ is just sufficient for a study. Table VII.1 shows the response rate.

\begin{tabular}{llll}
\multicolumn{2}{l}{ TABLE VII.1: RESPONSE RATE } \\
\multicolumn{2}{l}{ Response } & Frequency & Percent \\
\hline 1 & Returned & 80 & $71 \%$ \\
2 & Unreturned & 33 & $29 \%$ \\
\hline & TOTAL & 120 & $100 \%$ \\
\hline
\end{tabular}

\section{B. Regression Analysis Results}

The study sought to establish the influence of strategic inventory management practices on the performance of supermarkets in Nairobi County, Kenya. A regression equation in the form of: $\mathrm{Y}=\beta 0+\mathrm{a} 1 \mathrm{X} 1+\mathrm{a} 2 \mathrm{X} 2+\mathrm{a} 3 \mathrm{X} 3+$ a 4 X4 $+\varepsilon$ was used to establish the association between Performance (dependent factor) and SIMPs (independent factors). The study independent factors (vendor-managed inventory, lean inventory management system, e-inventory management system and activity based costing system) regressed against the dependent factor (performance) and the results are presented through Table VII.2. The model Coefficient of determination value, $\mathrm{R} 2$ was found to be 0.3155 indicating that $31.55 \%$ of supermarket performance was explained by Strategic inventory management practices (SIMPs). The results from table 3 show that the predictor equation for supermarket performance (Y) versus independent factors $(\mathrm{Xi})$ takes the form: 
Performance $=2.941+0.235$ (Vendor-managed inventory) +0.036 (Lean inventory management system) $+0.279(\mathrm{E}-$ inventory management system) +0.260 (Activity based costing system) +1.291 .

This implies that performance increases by 0.235 when vendor-managed inventory goes up by 1 index unit, increases by 0.036 when lean inventory management system increases by 1 index unit, increases by 0.279 when e-inventory management system increases by 1 index unit, and increase by 0.260 when Activity based costing system increases by 1 index unit. The study findings further indicate that einventory management system has the greatest influence on performance at 27.9 percent followed by activity based costing system at 26.0 percent, Vendor-managed inventory at 23.5 percent and the least is lean inventory management system at 3.6 percent.

TABLE VII.2: REGRESSION ANALYSIS RESULTS

\begin{tabular}{|c|c|c|c|c|}
\hline $\begin{array}{l}\text { Supermarkets } \\
\text { Performance }\end{array}$ & $\begin{array}{l}\text { Coefficient } \\
\text { (B) }\end{array}$ & $\begin{array}{l}\text { Standard } \\
\text { Error }\end{array}$ & $\mathrm{t}$ & $\begin{array}{l}\text { Sig } \\
\text { (p) }\end{array}$ \\
\hline $\begin{array}{l}\text { Vendor- } \\
\text { managed } \\
\text { inventory }\end{array}$ & 0.235 & 0.061 & 3.875 & 0.000 \\
\hline $\begin{array}{l}\text { Lean } \\
\text { inventory } \\
\text { management } \\
\text { system }\end{array}$ & 0.036 & 0.054 & 0.673 & 0.502 \\
\hline $\begin{array}{l}\text { E-inventory } \\
\text { management } \\
\text { system }\end{array}$ & 0.279 & 0.116 & 2.399 & 0.018 \\
\hline $\begin{array}{l}\text { Activity based } \\
\text { costing } \\
\text { system }\end{array}$ & 0.260 & 0.111 & 2.340 & 0.021 \\
\hline Constants & 2.941 & 1.291 & 2.277 & 0.025 \\
\hline
\end{tabular}

\section{Discussion of the Results}

The study sought to establish the influence of strategic vendor management practices on performance of supermarkets in Nairobi County, Kenya. A number of studies, for example, references [26], [4], [36], [40], [38], [39] have argued that SIMP practices lead to improvement of the performance of firms. This study postulation was grounded on such studies within the resource based view theory and activity based costing system theory. The study findings indicate that firms that have embraced SIMP practices within their operations experience improvement in their performance. The multiple regression analysis results indicate that SIMPs have a positive statistically significant effect on performance of supermarkets; $\mathrm{p}<0.05(\mathrm{P}=0.025)$ with an explanatory power of 31.55 percent. Therefore, the study question "Does strategic inventory management practices affect performance of supermarkets in Nairobi County" was answered in the affirmative which further addresses the study general objective "to establish the influence of SIMPs on the performance of supermarkets in Nairobi County. The findings of this study strongly agree with previous studies carried out by reference [4], [28] and supports resource based view theorists such as references [26], [4], [38], [40], [39] which established a positive and significant relationships between SIMPs and performance and advance strategic inventory management practices as a fast-forward management concept capable of giving a firm competitive advantage.

Further, the study established that within the strategic inventory management practices, e-inventory management system has the greatest effect on performance; $\mathrm{P}<0.05$ $(\mathrm{P}=0.018)$ with an explanatory power of 27.9 percent. This finding is in line with references [11], [19] and [31] studies which established that adoption of e-inventory management system within operations of firms increases performance through improved stock traceability, monitoring , replenishment and accuracy in recording and issuance. The second in line is activity based costing; $\mathrm{P}<0.05(\mathrm{P}=0.021)$ with an explanatory power of 26.0 percent. This finding agrees with references [4], [28] studies which established a positive correlation between $\mathrm{ABC}$ and right pricing of products to customers which make customers trust the firm and become loyal hence performance due to repeat purchases. Vendor-managed inventory registered the third highest effect on performance; $\mathrm{P}<0.05(\mathrm{P}=0.000)$ with an explanatory power of 23.5 percent. This finding concurs with references [10], [28], [31] studies which revealed that VMI positively influences firm performance through elimination of inventory holding costs. Finally, lean inventory management system registered none significant effect on performance; $\mathrm{P}<0.05(\mathrm{P}=$ 0.502 ) with an explanatory power of 3.6 percent. This finding contradicts reference [11] study which concluded that lean inventory management system increases cost efficiency, increases worker productivity and less waste of time and effort which in turn significantly improve customer satisfaction and store profitability. This could be due to weak supply chain systems and poor logistics infrastructure in Kenya compared to United States where reference [11] study was conducted. According to reference [19] for lean inventory management system to be successful, it requires efficient SCM system and a working logistics infrastructure.

\section{SUMMARY}

The study established a positive significant relationship between SIMPs and supermarkets performance based on the following constructs: e-inventory management system, activity based costing system, vendor managed inventory and lean inventory management system. However, e-inventory management system was found to be the one offering greatest influence on performance followed by activity based costing system and vendor managed inventory respectively. Lean inventory management system was found not to offer any significant influence on performance.

\section{CONCLUSION}

The study concludes that strategic inventory management practices indeed do influence the performance of supermarkets operating in Nairobi County, Kenya. This performance is most affected by e-inventory management 
system followed by activity based costing system, vendor managed inventory respectively. Further, the study concludes that lean inventory management system does not significantly influence the performance of supermarkets in Nairobi County. The study finally concludes that all the four factors of SIMPs combined positively and significantly affect the performance of supermarkets.

\section{RECOMMENDATIONS}

The study established that e-inventory management system, activity based costing system and vendor managed inventory respectively offer the greatest influence on the supermarkets performance. Consequently, the study recommends that supermarkets in Kenya should implement e-inventory management system, practice activity-based costing and collaborate with vendors to adopt vendor managed inventory concept with their operations in order to improve their performance through reduction of operation costs, improved inventory control and customers' service.

Further, the government should give tax rebate on IT infrastructure related to e-inventory management systems to encourage up take of the systems by firm as a way of boosting their performance and growth. The management of supermarkets should institutionalize employment of cost accountants as part of supply chain management team for effective application of activity based costing in inventory management. A structured collaboration between the vendors and supermarkets should be institutionalized to facilitate vendor managed inventory arrangement.

\section{SUGGESTION OF FURTHER READING}

The study suggests that future research should focus on undertaking a comparable study incorporating a larger population as well as research on elements affecting the effectiveness of strategic inventory management practices once they are implemented by supermarkets in order to obtain a comprehensive understanding of the subject matter and contribute towards literature in the area of study.

\section{ACKNOWLEDGMENT}

R. Arasa and J. Achuora wish to thank the heads of supply chain management of the respective supermarkets who supported this study through their participation as the respondents. The authors further thank the panel of reviewers at the EJBMR for their professional critiques which were used to enrich the paper. Finally, the authors acknowledge Machakos University management for allowing the authors to use the University infrastructure to undertake the study.

\section{REFERENCES}

[1] B.M. Beamon and S.A. Kotleba, "Inventory modeling for complex emergencies in humanitarian relief operations". International Journal of Logistics: research and applications, 9(1), 1-18, 2006

[2] D.Blanchard, Supply chain management: best practices (2nd ed.). New Jersey: John Wiley \& Sons, 2010.

[3] S. M. Diaz, Activity Based Costing System (ABC): Implementation In a Supermarket. Universitat Jaume, 2015.
[4] J. Fahy, The Role of Resources in Global Competition, London, United Kingdom, Routledge, 2002

[5] M. D.Gall, J. P. Gall and W.R. Borg, Educational Research: An Introduction (8 ed.). Utah, USA. Utah University, 2007.

[6] RoK, Kenya Vision 2030. Retrieved from http://theredddesk.org/sites/, default/files/vision 2030 brochure july 2007.pdf

[7] R.M. Grant, Contemporary Strategy Analysis: Text and Cases (8 edition). Chichester, West Sussex, United Kingdom: Wiley, 2013

[8] K.S. Harshitha, "Impact of Inventory Management on Financial Performance-A Comparative Study". Global Journal for Research Analysis, 5(11), 2017 Retrieved from https://worldwidejournals.in/ojs/index.php/gjra/article/view/13603

[9] J. Hoffman, Principles and Practices of Effective Inventory Management. West Sussex, England, John Wiley \& Sons Ltd, 1997.

[10] B.K. Irungu and K.L. Wanjau, "Effectiveness of vendor managed inventory systems in retail supermarkets in Kenya". International Journal of Business and Public Management, 1(1), 85-89, 2011

[11] M. Iwase and K. Ohno, "The performance evaluation of a multi-stage JIT production system with stochastic demand and production capacities. European Journal of Operational Research, 214(2), 216222,2011

[12] A. Jankowicz, Business Research Projects, 3rd Edition, Thomson Learning, London, 2000

[13] I. M, Kariuki, Challenges and survival strategies of supermarkets in Nairobi, Kenya (Thesis). University of Nairobi, Nairobi, Kenya, 2011. Retrieved http://erepository.uonbi.ac.ke:8080/xmlui/handle/11295/12352

[14] J. Katz, Forecasting: Strategic Inventory Management, 2006. Retrieved from IndustryWeek: http://www.industryweek.com/leansix-sigma/forecasting-strategic-inventory-management

[15] C. K. Kothari, Research Methodology: Methods and Techniques, 2nd Edition. New Delhi: New Age International Publishers, 2004.

[16] R. Kumar, Research Methodology: A step-by-step guide for beginners (2nd ed.). London: SAGE Publications Ltd, 2008.

[17] P. S.Levy and S. Lemeshow, S. (2008). "Sampling of Populations: Methods and Applications (4th ed.)". John Wiley \& Sons, Inc. doi:10.1002/9780470374597, 2008.

[18] M. A. Lewis and J. K. Roehrich, "Contracts, relationships and integration: towards a model of the procurement of complex performance". International Journal of Procurement Management, 2(2), 125-142. https://doi.org/10.1504/IJPM.2009.

[19] R. Lukic, "The Effects of Application of Lean Concept in Retail". Economia. Seria Management, 15(01), 88-98, 2012.

[20] E, B. McCullough, Transformation of Agri-Food Systems. Globalization, Supply Chains and Smallholder Farmers. Earthscan, 2012.

[21] O.M. Mugenda and A. G. Mugenda, Research Mehtods: Quantitative, Qualitative Approaches. Nairobi: ACTS Press, 2003.

[22] K. Mungai and Kibubi, Benchmarking Practices and Performance of Supermarkets in Nairobi County (Thesis). UON, Nairobi, Kenya, 2016. Retrieved

from http://erepository.uonbi.ac.ke/xmlui/bitstream/handle/11295/100162/

[23] B.N. Mwiriki, Strategic change management practices and perfomance of large supermarkets in Nairobi County, Kenya (Thesis). Nairobi, Kenya, University of Nairobi, 2015. Retrieved from http://erepository.uonbi.ac.ke:8080/xmlui/handle/11295/95174

[24] J, M. Mburu, The Relationship between Inventory Turnover and Financial Performance of Supermarkets in Kenya. (Thesis). Nairobi, Kenya, UON, 2013. Retrieved from http://erepository.uonbi.ac.ke/bitstream/handle/11295/59696/Mburu_ The \%20Relationship $\% 20$ Between $\% 20$ Inventory\%20Turnover\%20An $\mathrm{d} \% 20$ Financial $\% 20$ Performance $\% 20 \mathrm{Of} \% 20 \mathrm{Su}$.

[25] Ö. Özer and W. Wei, "Strategic Commitments for an Optimal Capacity Decision". Decision Under Asymmetric Forecast Information. 52(8), 1239-1258, 2006.

[26] M. Peteraf, Resource-based theories. In M. Augier \& D. Teece (Eds.), the Palgrave Encyclopedia of Strategic Management. Palgrave Macmillan, 2015. Retrieved from http://www.palgraveconnect.com/doifinder/10.1057/9781137294678. 0588

[27] PWC, So much in store. Prospects in the retail and consumer goods sector in ten sub-Saharan countries (pp. 1-106). South Africa: PWC, 2016. Retrieved from http://www.pwc.co.za/en/press-room/retail-inafrica.html

[28] H. Ravinder and R.B. Misra, "ABC Analysis for Inventory Management: Bridging the gap between research and classroom" American Journal of Business Education (Online), 7(3), 257-264, 2014

[29] J. Rice, Mathematical Statistics and Data Analysis (2nd ed.). Pacific Gorve, CA: Duxbury Press, 1995. 
[30] M. Saunders, P. Lewi and A. Thornhill, Research Methods For Business Students. Prentice Hall, 2003.

[31] D. Yu, Vendor Managed Inventory in the Swedish Construction Industry, 2010. Retrieved from http://publications.lib.chalmers.se/records/fulltext/128303.pdf

[32] KNBS, Kenyan Economic Survey, Nairobi. Kenya, Government Printer, 2017.

[33] T. Yamane, Statistics: An Introductory Analysis, 2nd Edition, New York: Harper and Row, 1967.

[34] J. Neyman. "The approach to statistical hypothesis testing, Journal of the Royal Statistical Society, Vol. 97, No. 4, pp. 558-625, 1934.

[35] J. C. Nunnally and I.H Bernstein, Psychometric theory (3rd ed.). New York, NY: McGraw-Hill, Inc, 1994.

[36] R. Kaplan and S.R. Anderson, Time-Driven Activity-Based Costing: A Simpler and More Powerful Path to Higher Profits. Harvard Business School Press, 2007.

[37] Shaban, Activity Based Costing, ABC Adoption and Success factor: A paper to Faculty of Economics and Business Administration, Vrije Universiteit Amsterdam, 2009.

[38] Adamu and A. I. Olotu, "The practicability of activity based costing system in hospitality Industry". A Journal of the Department of Accounting, Nasarawa State University, 1, 36-49, 2009.

[39] Kaplan, S. Robert and W. Bruns, Accounting and Management: A Field Study Perspective, Harvard Business School Press, 1987, ISBN 087584-186-4

[40] R. Garrison, E. Noreen and P. Brewer, Managerial Accounting, McGraw-Hill, 2012

[41] P.F. Drucker, Management Challenges of the 21st Century. New York: Harper Business, 1999

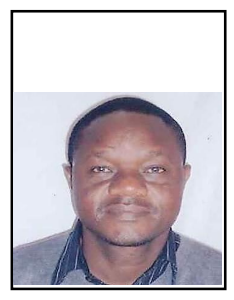

Prof. Robert Arasa holds a $\mathrm{PhD}$ in strategic management, MBA and Bcom from University of Nairobi. He has over 15 years of corporate experience serving in various positions including; Branch Manager, Marketing Manager, Business Development \& Research Manager for Kenya's National Health Insurance Fund. He has over 10 years' experience in academia having served as senior lecturer (Strathmore University - Kenya, Director - Graduate Business School (Catholic University of Eastern Africa) and currently as Associate professor and Coordinator of Post graduate programme (School of Business \& Economics, Machakos University, Kenya). He has published in areas of strategy, supply chain management, entrepreneurship and Human Resource. Arasa serves as a reviewer for Issues in Business Management and Economic Journal, International journal of Educational Policy and Review and is in the editorial team of IPRJB publishers. He has also provided consultancy services to organizations within the public and private sectors in areas of strategic plan, performance management, management surveys and various management capacity building programmes. Arasa is Research Associate of Institute of Policy Analysis \& Research (IPAR - Kenya), a member of Kenya Institute of Management (KIM) and Marketing Society of Kenya (MSK).

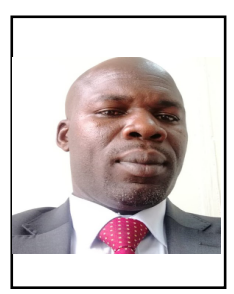

Achuora John was born in Migori County, Kenya in 1st August 1978. In the year 2015, he earned a PhD degree in Supply Chain Management from Jomo Kenyatta University of Agriculture and Technology, Juja, Kenya; in 2011, he earned MSc. degree in Procurement and Logistics Management from JKUAT, Juja, Kenya and in the year 200, he earned Bachelor of Commerce degree (Accounting) degree from Sukhadia University, Udaipur, India.

$\mathrm{He}$ is a researcher who has worn several grants and published several authoritative papers in reputable journals in the area of SCM. He lectures and coordinates exams at Machakos University, Machakos Town, Kenya. He is an external examiner at Management University of Africa, adjunct lecturer at Masinde Muliro University of Science and Technology and a reviewer of Global Scientific Journal. He was supply chain Management leader at Itumo International Ltd, Procurement Manager at United States International University- Africa, Assistant Procurement manager at Hyoung and Co. E.A. Ltd, and Procurement officer at Icon Telesec Services Ltd.

Dr. Achuora is a Supply chain Management specialist and Procurement Systems developer and Analyst, Certified Procurement Practitioner by Kenya Institute of Supplies Management, Certified International Procurement Practitioner by IAPM, licence supplies management practitioner by KISM and a Member of Kenya Institute of Management (KIM). 